左湖々頭面の振幅が比較的大きく，3，7，17，19，26 及び27 の振幅が 比較的小さく，量ての挴動位相は 同じでる. 矢狀方间では同稳 $3,7,17,19,26,27$ 质び側頭面の振輻务比較的小さく，5，18，27，29,22

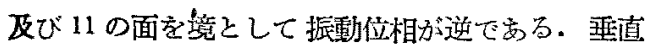
方向ではドイッ水平面る境として振陲の位相が逆で ある以外には著明な特長はない。

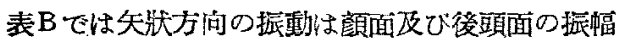
が比較的大きく，3，12，17，16，29 の振邦畐が小さく，

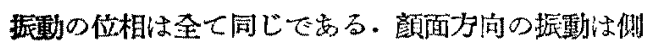
頭面の振幅が比較的大きく，3，12，17，26 及灭び 29 の振幅が同樣に小さく，振動の位相は 14，24，30，

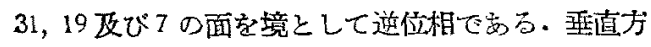

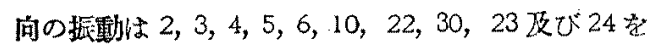
通る面を境として振動の位相が逆で岕る。

$1000 \mathrm{cps}$ での頭蓋抎動は表Aては頝面方向の振動は 5, 10 及び11 の振幅が大きく，4，7，12，18，19，21， 22 及び 27 の振幅が比較的小ざい，振動D位相は
$5,8,13,14,18,20,21,23,24,28,29$ 飞び 30 と他

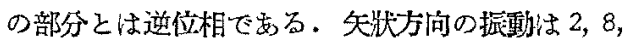

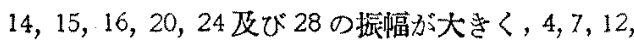
$18 ， 19,21,22$ 及び 27 の控幅各小さい. 振動の位相 は 5，18，27，31，29，21，10を通る面を境として通楿

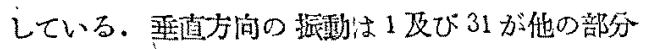
飞比して大きい. 振動の位相は 2, 3，4，5，7，8，21， 22,230面走境として位相か逆である。

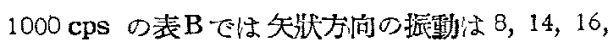
20,24 及び 25 で振幅名比較的大きく，1，3，7，9，13， $17,19,21,23,26,28$ 叐び 30 が小さい. 振勘の位相 は2,6,10,14,16,17,19,21,24,25,26,27 及び 29 と他の部分とは逆でるる。顏面方向では 5, 11,

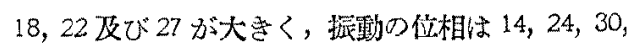
29 及び 20 を通る面を㑽として逆轉する。垂直方何 では 1 及び 31 が振幅が大きく，2，3，4，5，7，8，21， 22, 23 の面を境として位相が逆轉寸る.

(愿陪到酷二招和 28.9 .4 日)

\title{
S. KAWAMURA, M.D.: EXPERIMENTAL STUDIES ON THE VIBRATION PATTERNS OF THE HEAD
}

\section{頭蓋の振動とその樣式に關する實驗的研究（2）}

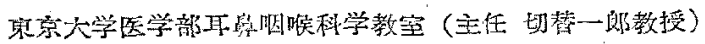

$$
\text { 医学士滒 村 正 }
$$

\section{第4章 繒括並に洘按}

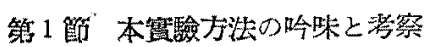

使用した留置の特性梳 Fig.2 に示した如くで比

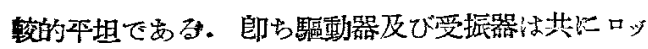

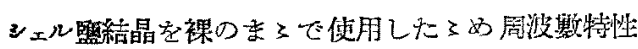
か比較的是好で出つた。

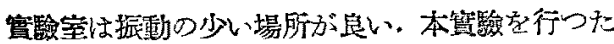
のは鉄筋ニンタリート造りの起物でするが，廊下壳

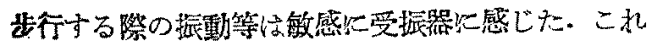

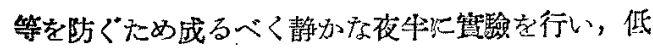

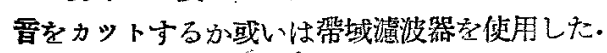

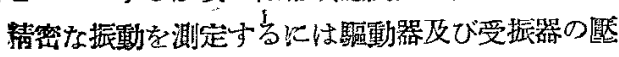

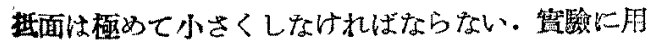

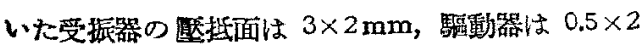

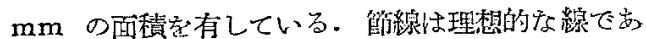

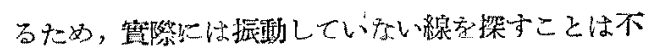
可能で京り，この場合は位相の變化を目䅺炕しなけ ればならなかつた。

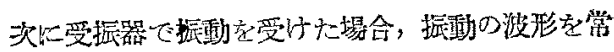

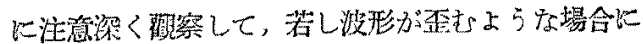
はその原因を洫案して取除か秝ばならなからた・た

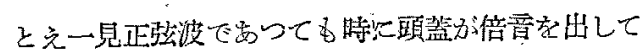

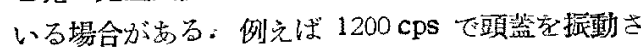

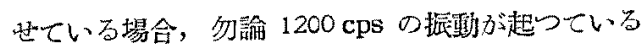
が，それよりす非常に大きく $2400 \mathrm{cps}$ の固有振勤 整で振動小るようなことが要る。この場合化正弦波

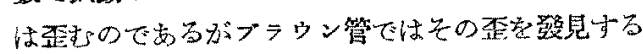

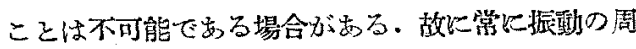




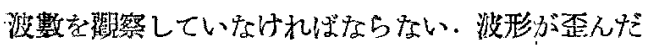
り或いは倍音が出たりする場合の最す参い原团は刺

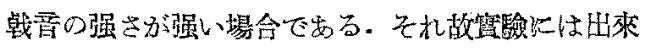
るゲけ小さい音を使用しなけ狄ばならず，そのため

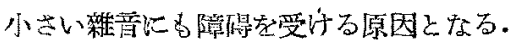

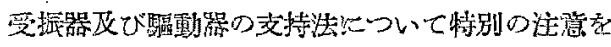
拂つた交献は礼いが，余り强くこれを固定台比支持

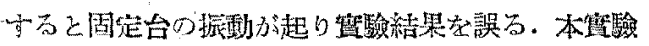

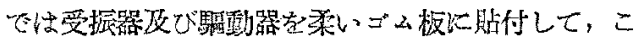
のゴム板家固定台に取的けその影留を防いだ。

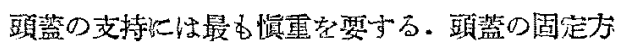

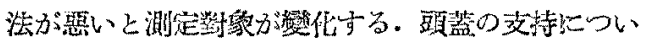

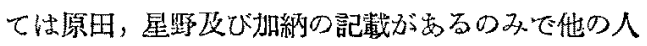
人は如何に法持したかは交献上推察す百ことは出來

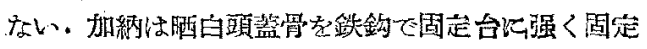
して，その固远台を更飞萬力て机取付けている. この場合頭篮骨と鉄鈎との間にはゴム，綿を倠用し

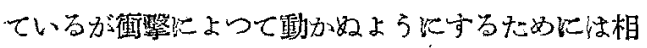
蒏强く固定したすのを想像される・ゴム文び綿はそ

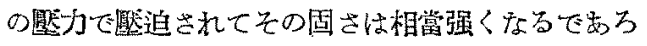
5.この上万な方法では頭蓝骨と固定台と机とが全 く一りの振動体として振動すると考光る.しかす の質䁷は晒白頭藍骨比比し机等が余りに大きい。

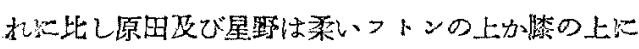

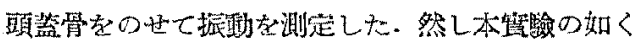

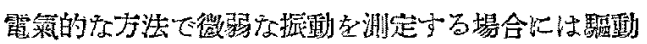

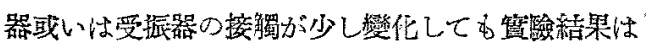

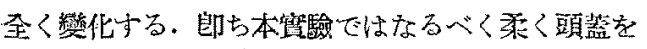
车えるた妙比前記の固定方法を行つた（第2 等，第 2 節, 第 2 項).

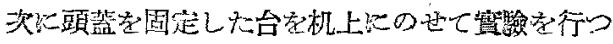

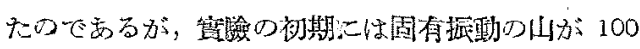

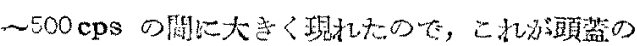

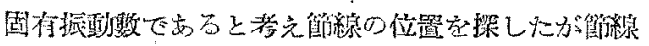

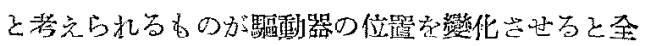

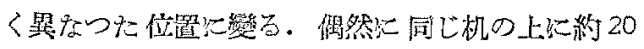

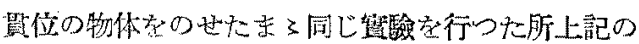

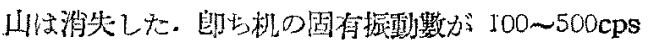

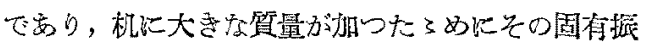

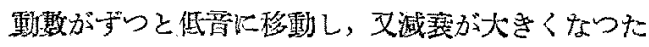

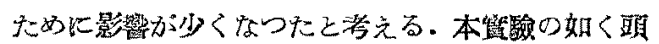

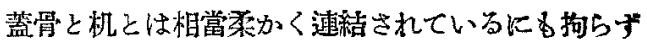

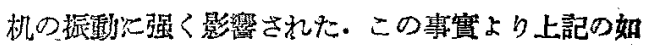

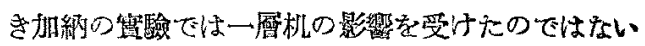

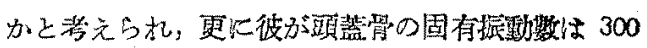

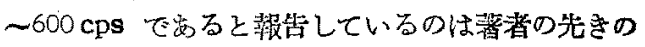
失敗した周波慗と余りとる一致している。

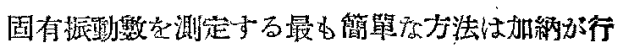

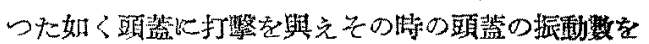
分析寺狄ばょいのであが，この方法では多くの固 有振動数京發見することは国蜼である。Bákésy は

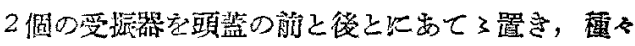

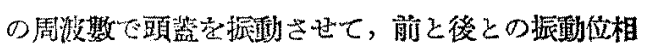

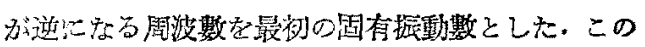
方法法物理的些考えて不合理でる。著者の用いた 法は小橋が鐘の振動を測定するのに用いた方法と

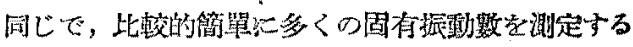

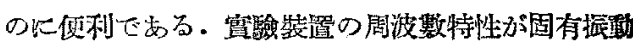

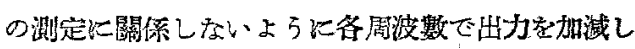
た.しかし一定の節線が存在することに上り固有层 毁數は汽等的上なる。

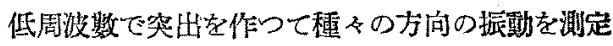
しょらとしたが䁈際こは受振器の性質上一方向の振 動のみ意測ることは不可能である。受振器のあて方 とよつてその方向の振野が他の方向の振野化比して

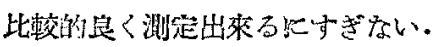

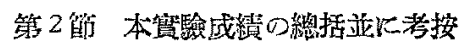

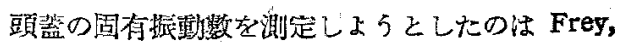
Goldberger \& Schön, Bíkśsy，收び加紟である.

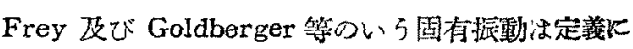

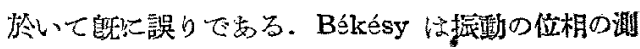
定上り顗篮の最初の国有振動數恃 $1800 \mathrm{cps}$ 附近厄

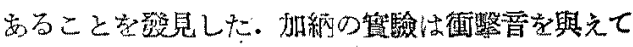

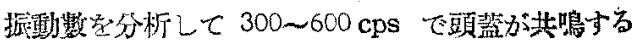
と記载している。

著者の測定成績は Table I 代示した如く理々條

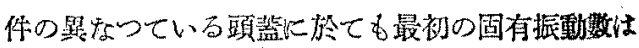
1700 万至 $1800 \mathrm{cps}$ であるこの結果は Bókésy の測定結果と全く一致している. $1800 \mathrm{cps}$ 上り高い 固有抵政数代ついての測定は未だ交献上より見出せ 广a. 


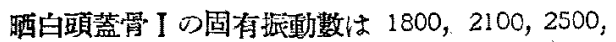
$2700,3100,3200,3500,3700,4000$ cps で明白頭盐 骨佶 $1700,2000,2300,2700,2900,3200,3800$ 工

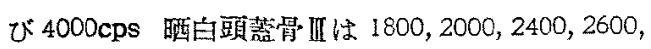
$3000,3400,3700$ 及び $3900 \mathrm{cps}$ である. 䁌白顽蓝 骨の大さは正名最す大きく、次いで，最む小さい

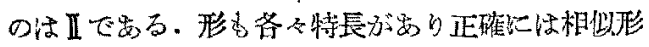
ではない，固有捺動數は非常によく一致しているが

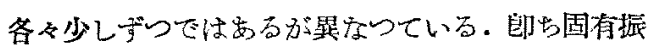

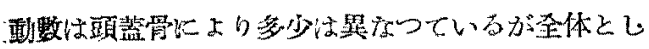

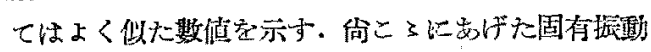
數は此较的よく現和机た $4000 \mathrm{cps}$ またのるのだ

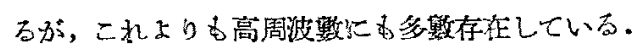

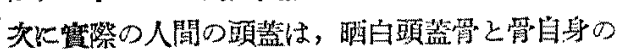

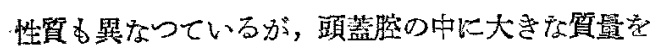
すつ䐉の存在が层動に大きく作用するのではないか

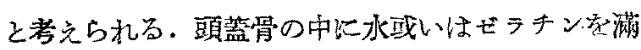

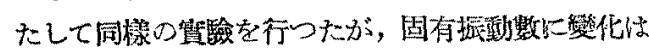
なからた・ビーカーの中に水を入れるとビーカーの

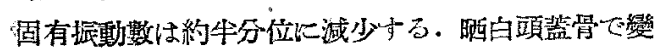

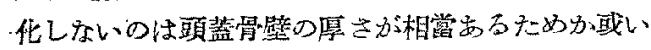

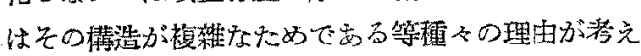
られるが明らかではない。

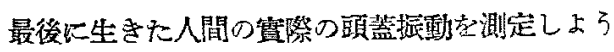

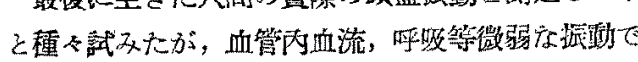

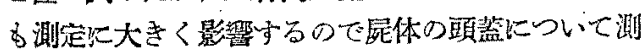
定した。この場合も，皮膚者有していてもいなく

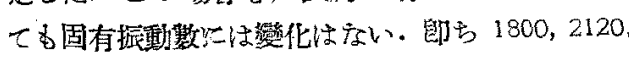
$2700,3100,3800 \mathrm{cps}$ て岕万. これと晒白頭盐骨の とを比較してみると $2500,3200,3500 \mathrm{cps}$ の固疗 振動數が屋体では存在していないが，他はほはり上

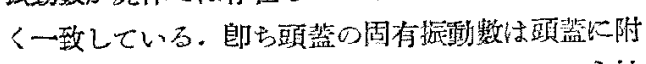

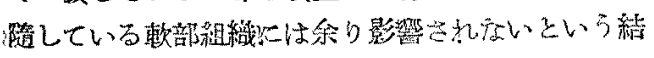

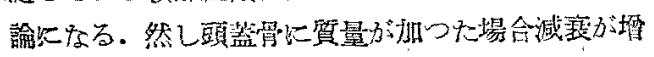

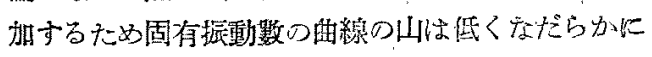

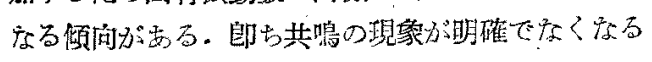
候问をるつている。

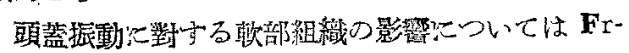

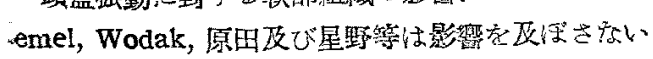

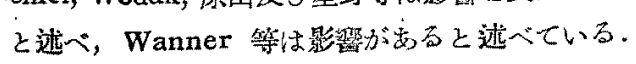

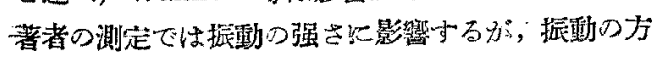

法には影嘼しない。

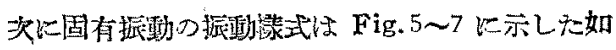

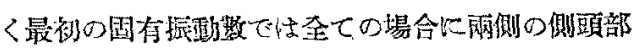

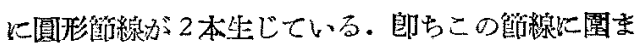
れた部分が四むと他の部分性笑出し，突出与ると他

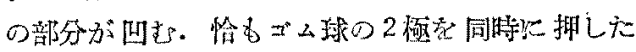
り，引いたりした待のように振動ず、 Békésy

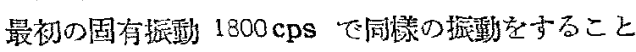

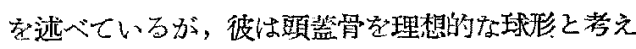

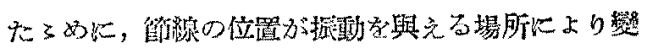

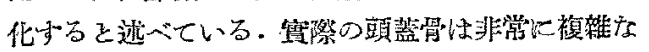

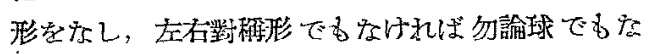

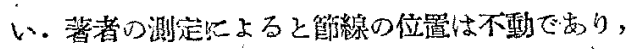
逆汇このことがその周没整が固有振動整であるとい

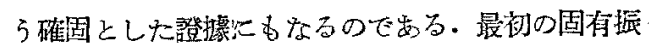
動の次の固有振動數では頭盐骨 I，II 及び屋体では

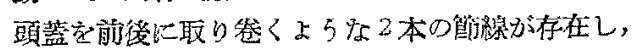

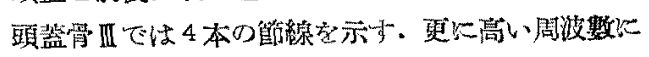

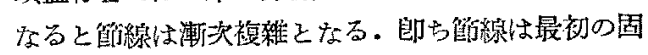

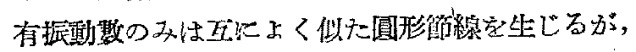

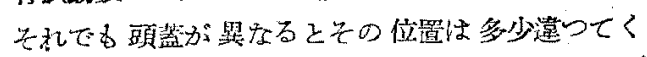

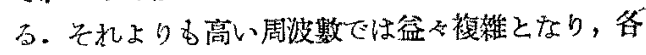

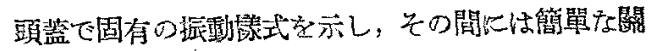
保は見出世なからた。郎ち $1800 \mathrm{cps}$ 附近より高い

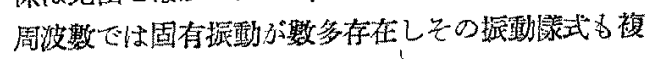
㺗である。

次に $1800 \mathrm{cps}$ より低い周波数で顽蓋がどの上5

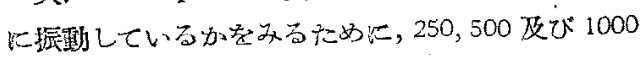

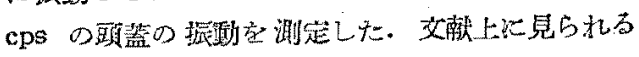

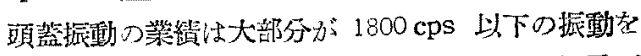
取扱つたものである。郎ち Lucae, Kessel 及び

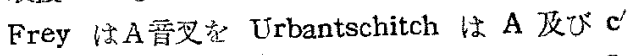

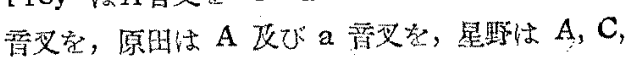

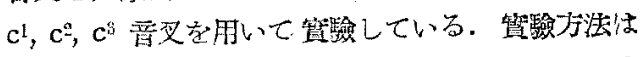

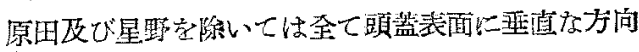
の层䡃わみ在测定したるのだ，之については原田の

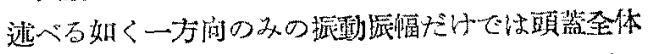
の振動壳知ることは不可能でする。師ち原田は頭篮

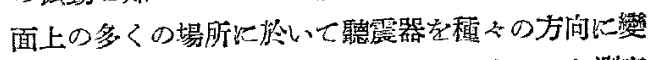
化させて最す振幅の大きい方向ととの大さと老測定

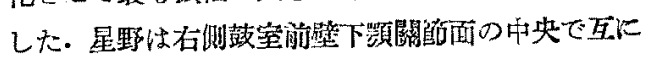


Fig. 8

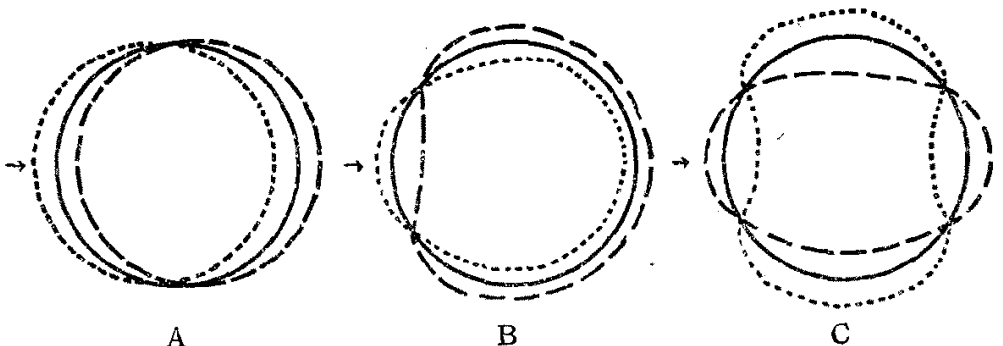

A

直角に交わる方向の振動を湘定しているが，測定場

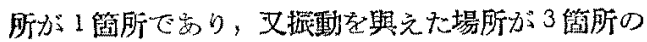
々であるので頭㙋圣体の振野を知ることは出來なか

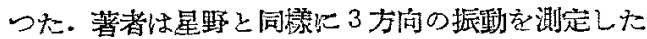

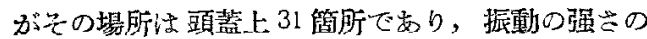

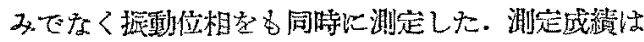
Table 2 飞示した.

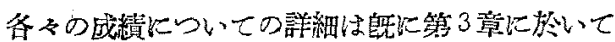

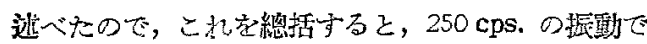
は與えた振動飞同じ方向の桭動旅䐺は全ての場所で

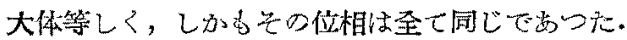

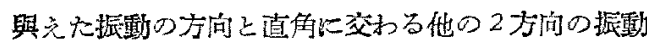

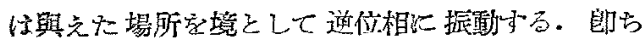
$250 \mathrm{cps}$. ては Fig. 8 のA K模型的に示したように

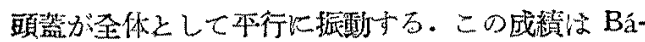

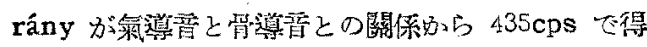
た綕果，剆ら mass-movement と一致している。

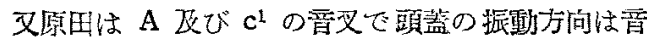

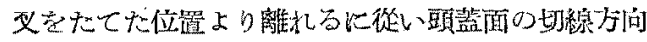

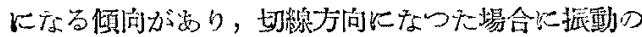
强さが最小となるが，この場所を過ぎると唡び與兑

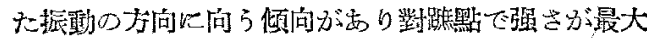
そなると速べている。この中で振幅の大さ空除いて

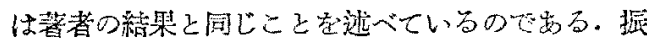
幅の大ざりいては原田の测空方法では切線方向の

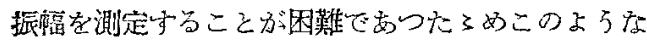
結果が出たので恬いかと栲光られる。

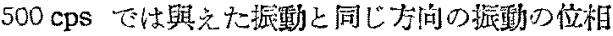
は坴て同じで㐫り，與穴た振動の方向と直角に交わ る他の 2 方向の层怔站相は振動家與えた點を境とし て兩側で逆となる。匀振幅の小さい場所は3方间で
其通していることはこの場所が節となつていること を示している. 即ち $500 \mathrm{cps}$ では Fig. 8 の B

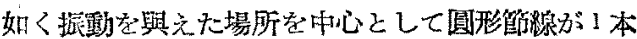
現秃孔る・この結果は Bákśsy が $800 \mathrm{cps}$ で得た 絓果と贷ている。

$1000 \mathrm{cps}$ での嘼蓝振動は，與之た振黠と同じ方 问で偣相は同位租の場所々逆位相の場所とが交互に

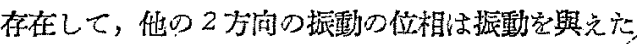

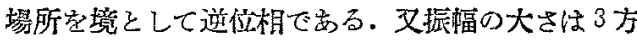

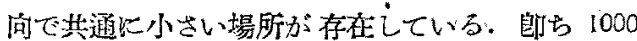

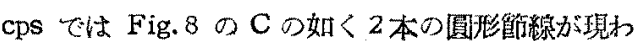
れる、この結㪙は Békésy が $1600 \mathrm{cps}$ て得た結果 と一致している.

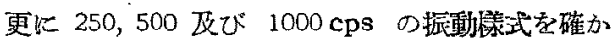

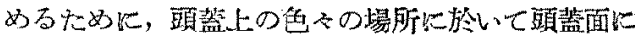
垂直な方向の振動位相の㑏測定行い Fig. 8 飞示し た振初㧺式て振動していること確認した。

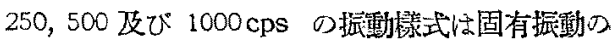

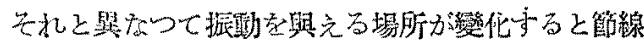
が移動主る。

以上の結果齐綜合すると頭篮は $250 \mathrm{cps}$ 附近の 低い周波數では全体るして平行に渾動する。朗ち mass-movement t在5. $500 \mathrm{cps}$ 附近の周波般大

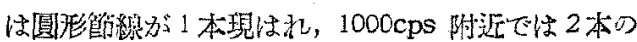

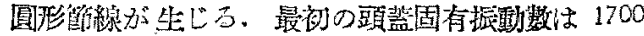

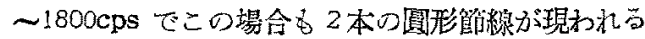

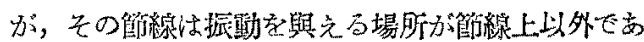

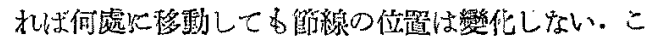
れ上り高い周波數 $2000,2300,2700,3000 \mathrm{cps}$ 等多

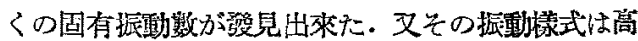
い周波嘍となるに從い複雜となる。 
Hirsh は Bárâny 及び Bókésy の實簽結果より 低周波數では頭蒡は mass-movement を行うのた

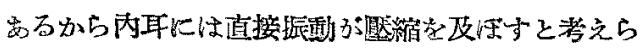

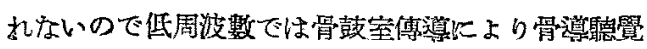

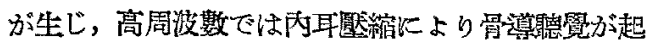

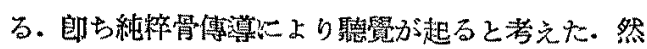
しこの推論の如く䫒蓝の mass-movement そ內耳

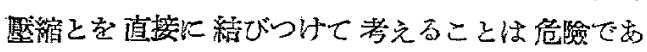

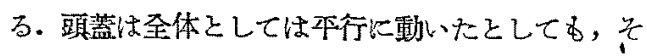
れは交くなで近似值的ですり，頭蓝法決して理想的 な㓮体ではない故內耳には壓縮は勿論のこと種々褐

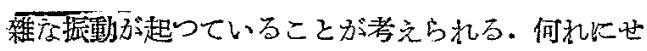

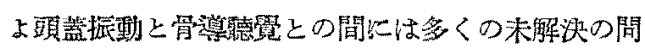
題が存在している。

\section{第 5 章 結 論}

唒白頭蓋骨 3 個及び屋体頭藍についてロッシエル

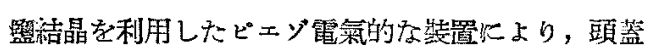

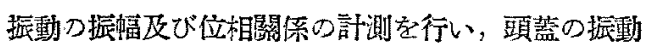

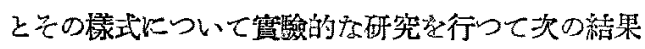
老得大.

1, 頭蓋の最す低、固有振動數住 $1700 \sim 1800 \mathrm{cps}$ でる。

2. 頭蓋の固有振動㖣は更に $2000,2400,2700,3000$, $3200,3500,3700$ 皮び $4000 \mathrm{cps}$ で，わつと高い䦌 波數炕數多存在している.

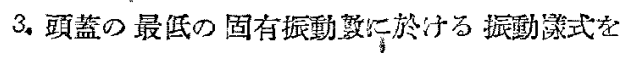

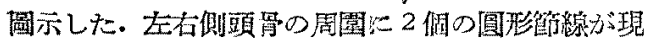
呩軋る。

4. $1800,2000,2400,2700 \mathrm{cps}$ の振動羕式を圖示 した・周波數が高くなるに從い算線の數を壻し、形

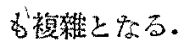

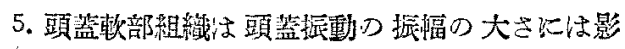

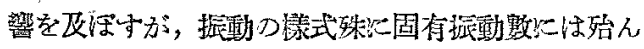
ぞ影響しない。

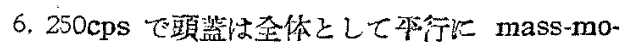
vementを行了。

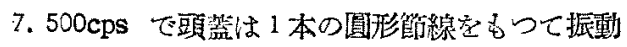
守古。

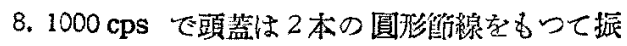
$4-23$
動与了。

9. $250 \mathrm{cps} 500 \mathrm{cps}$ Zび $1000 \mathrm{cps}$ の周波數で振

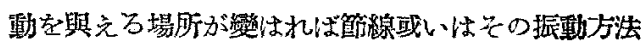
は覞則的炕變化する。

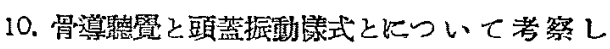
t.

\section{交嗝}

1) E. Bárány: A contribution to the physiology of bone conduction: Acta otolaryng,; 26. $1-223,1938 . \quad 2)$ B. Becker: Zones of the skull of maximal and minimal sound propagation : Laryngoscope; 42. 588-593, 1932.

G. v. Békésy: Zur Theorie des Hörens bei der Schallaufnahme durch Knochenleitung: Ann. d. Phys.; 13.116-136, 1932. 4) G. v. Békésy: Vibration of the head in a sound field and its role in hearing by bone conduction : $\mathbf{J}$, acoust. Soc. Amer.; 20.749-760, 1948. 5) F. Fremel: Über die Knochenleitung bei Kopfschüssen; Monatschr. f. Ohrenheilk.; 52. 187-203, 1918. 6) H. Frey: cit. after Runge. 7) K. Goldberger $u . S$. Schön: Die neue Schädelresonanzprüfung $\mathbf{u}$. ihre Bedeutung für die Ohren u. Nasennebenhöhlendiagnostik; Zeitschr. f. Hals usw. Heilk.; $12,578-587,1925 . \quad$ 8) $A$. Iwanoff: cit. after Runge. 9) J. Kessel: cit. after Runge, 10) A. Lucae: Untersuchungen über die sogenante "Knochenleitung" u. deren Verhältniss zur Schallfortpflanzung durch die Luft, im gesunden u. kranken Zustande: Arch. f. Ohrenhoilk.; 1: 303-317, 1864. 11) C. Ruf: Untersuchung über die Schallleitung im Schädel; Zeitschr. f. Hals usw. Heilk. : 31, 356-369, $1932 . \quad$ 12) H. G. Runge: Utber die Lehre von der Knochenleitung u. äber einen neuen Versuch zu ihrem weiteren Ausbau: Zeitschr. f. Hals usw. Heilk. : 5, 289, 1923. 13) H.G. Runge: Handbuch d, norm. u. path. Physiol., A. Bethe; S. $436,1926.14)$ V. Urbantschitsch: Úber die von der Höhe 


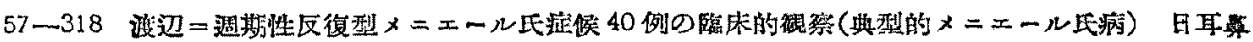

des Stimmgabeltones $u$. von der Applikationsstelle abhängige Schallleitung durch die Kopfknochen: Arch. f. Ohrenheilk:; 12. 207-220, 1877. 15) F. Wanner: Funktionsprüfung bei Lues: Verh. dtsch, Otol. Gesel.: 20. 229, 1911. 16) F. Wanner u. G. Gudden:, SchaIlleitung der Schädelknochen bei Erkrankung der Gehirns a. seiner Häute: Neurol. $Z$ tbl. 19. 883. 17) E. Wodak: Knochenleitung u. Lues: Monatschr, f. Ohrenheilk,; 54, 337-352,

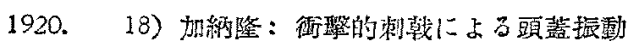
の研究，金沢大学，松日教授閉讙20周年記念論支

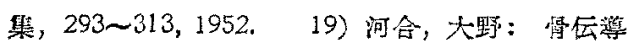

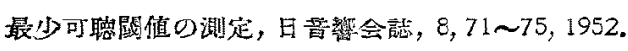

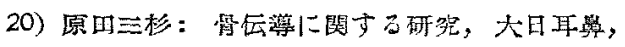

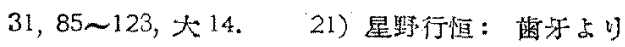

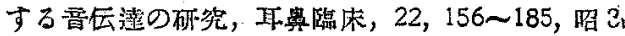

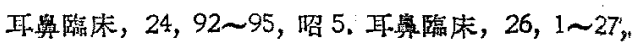
炤 6.

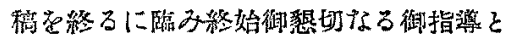
御校閵学賜わつた切替一郎教授, 併びに色 色々御便宜をいせゔいた小林理研小橋豊㣀 士飞㮌天堂医大池田修三教授に深謝し，僧

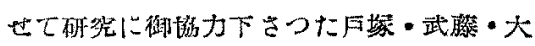

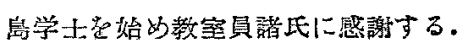

本研究には昭租 $26,27,28$ 年度定部省科学研

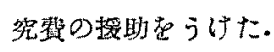

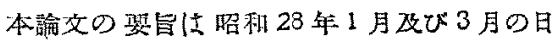

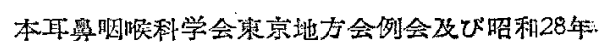
11 月日本需整学会総会に於て報告しだ。

（原稿到着二侣利 28.9.4 日）

\section{WATANABE, M.D.: A CLINICAL OBSERVATION OF 40 CASES OF MÉNIËRE' S SYNDROME WITH PERIODICALLY REPEATED ATTACKS (TYPICAL MÉNIÊRE' S DISEASE)

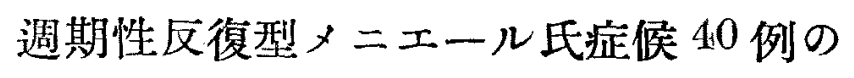$$
\text { 臨床的觀察（典型的メニエール氏病）（1） }
$$

目次
I 緒言
II 症例の選択荣件

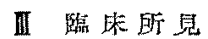
1) 年令，性別，職俈
2）全身状照欢び比往姃
3) 耳然咽㘈局所々見

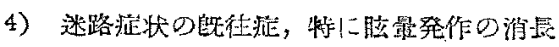

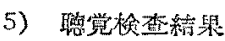
6）前庭阵能梌查所見
7) 治跨及びその欲の経過
IV 榙按
$\nabla$ 総括及び絬語

\section{I. 粕言}

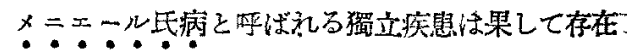
するであららか?，若しこ机が存在するとすれい゙， その典型的な或いは基本的な臨休像はどんなるだ ある5か?。

これが本論文の中心間題で出る。

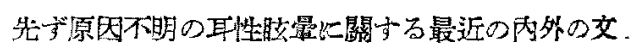
献1)-18) を通覧すると，少軗の例外 17)，18) 除いて メニエール上涴なる各程を次の樣な绦件を蔳足する

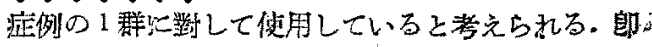
ら既にこ扎を臨床的に虽立疾患として取报つている。 のである。 